\title{
Upholding parental responsibility by family mediation: revisiting the role of the law for children in divorce in Hong Kong
}

Sau-wai Law

\author{
Department of Law and Business, Hong Kong Shue Yan University, \\ Hong Kong SAR, China
}

\begin{abstract}
Purpose - This paper aims to analyse the different requirements of Practice Direction 15.10 (which governs the process of family mediation in Hong Kong) and Practice Direction 31 (which governs the process of general mediation in Hong Kong), and to highlight the need to incorporate the spirit of family mediation into legislation to better protect children's interest in a family dispute.

Design/Methodology/approach - The paper reviews and compares the content on Practice Direction 15.10 and Practice Direction 31 issued by Chief Justice of the Hong Kong Court of Final Appeal, and adopts interpretative and analytical approaches to evaluate their impact.

Findings - In an effort to promote parental responsibility-based negotiation in divorce proceeding, a missed opportunity in enacting the Children Proceedings (Parental Responsibility) Bill in 2015 might be a blessing in disguise as it offers another chance for policy makers to consider how to direct parties to negotiate and communicate, to seek and benefit from professional guidance on a continuous basis, and to seek alternative channels to resolve disputes other than the court room. The policy and the law advocating a switch from a "rights-based" to "responsibility-based" approach in handling children's matters should be revisited by incorporating the spirit of family mediation into legislation.

Originality/value - Analyses are conducted through direct contextual review and documentary research. This paper conducts literal analysis of court guidance and unveils policy implications for the general public. It would be of interest to judicial officers, scholars and government officials concerning children's rights and parental responsibility in divorce proceedings.
\end{abstract}

Keywords Family mediation, Civil Justice Reform, Hong Kong public policy, Children's rights, Rights-based negotiation, Responsibility-based negotiation

Paper type Research paper

\section{Introduction}

The notion that parents are best positioned to resolve family matters involving children is deeply rooted in our society but what if the parents have decided to separate and are hostile towards each other? Resorting to litigation may be one way out but just as the Chinese proverb puts it, "Even the upright judge finds it hard to settle family matters." A Working Group appointed by the Chief Justice in 1997 recognized that a non-adversarial approach in resolving disputes arising from marital breakdown would minimize the attendant trauma and acrimony which may adversely affect the welfare of children, and that the parties are more likely to comply with the agreement (Hong Kong Legislative Council, 1999), the Judiciary accepted the recommendation of the Working Group and launched a 3-year Pilot

(C) Sau-wai Law. Published in Public Administration and Policy. Published by Emerald Publishing Limited. This article is published under the Creative Commons Attribution (CC BY 4.0) license. Anyone may reproduce, distribute, translate and create derivative works of this article (for both commercial and non-commercial purposes), subject to full attribution to the original publication and authors. The full terms of this license may be seen at http://creativecommons.org/licences/by/4.0/legalcode

I am most grateful to Professor Peter Fong and Dr Alice Te for their guidance in publishing this paper. I am also obliged to Ms Sze Sze Yuen, Mr. Martin Lau and others for their helpful insights.
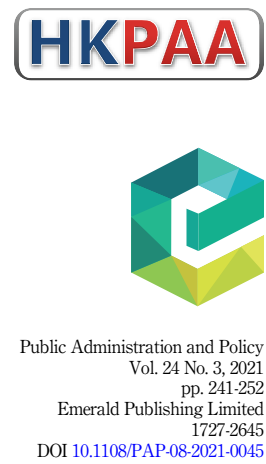
Scheme on Family Mediation in 2000 ("Pilot Scheme"). The result of the Pilot Scheme was promising. Over 70 percent of family cases submitted to court were suitable for family mediation of which 70 percent had successfully reached full settlement using an average of 10 hours per case. It has saved over 204 court days (Judiciary of HKSAR, 2021). The process was highly regarded as an efficient process and has been made permanent since then. The Chief Justice issued the Practice Direction 15.10 - Family Mediation ("PD15.10") (Chief Justice, 2012a) which first came into effect in April 2000, laying down the procedure to conduct family mediation in matrimonial proceedings. A coordination office which is now called the "Integrated Mediation Office" has been established to assist parties who are seeking family mediation services. A booklet "Family mediation: guide to court services" ("The booklet") (Hong Kong Judiciary, 2019) has also been published to provide further guidance to the public.

This paper explores what it takes to better protect children's interest in matrimonial disputes through the promotion of family mediation. Two documents issued by the Judiciary were examined: the PD15.10 (Chief Justice, 2012a) and Practice Direction 31 Mediation ("PD31") (Chief Justice, 2014). They provide supplemental protocols to assist in the conduct of mediation in court proceedings. Through critical analysis and comparative studies of the two documents, this paper seeks to re-draw stakeholders' attention to the function of family mediation and advocates that negotiation on children's post separation arrangement should be child-centric and be based on parental responsibility rather than parental rights over the children. To this effect, the unsuccessful attempt to enact the Proposed Bill of Children Proceedings (Parental Responsibility) Bill in 2015 ("the Proposed Bill") (Hong Kong Labour and Welfare Bureau, 2015) might well be a "blessing in disguise" in a sense that the stakeholders now have more time to reflect on whether the paradigm shift can be achieved through a consensual approach such as family mediation (e.g., Lynch, 2019). It also allows the Administration to adopt a wholesale approach in perfecting the law, policy, and professional assistance required to create a more meaningful impact.

The comparison of the two documents appears to suggest that the court could have provided more information in aiding lawyers and parents to adopt family mediation in resolving children-related matters, yet relying on the Practice Direction alone might not achieve this purpose. For example, the role of the integrated office which monitors and ensures the quality of family mediators, and the smooth administration of the process could be made more explicit to the public through the booklet. Also, family mediation could be made a necessary or even mandatory process should the Children Proceedings (Parental Responsibility) Bill be proposed again.

\section{Mediation and family mediation}

What is mediation and family mediation

There is no unified definition for "mediation". The word can trace its root back to the word "mediatus", with Latin meaning "placed in the middle". It is now commonly referred to a process in which an acceptable, impartial, and neutral third party who has no adjudicative power, intervenes in a dispute or a negotiation and assists the parties thereto in reaching a mutually acceptable settlement or agreement voluntarily (Moore, 2003). It is often held in private (Yarn, 1999), and the third party applies dispute settlement techniques in relation to negotiation process so that the disputants' minds could be influenced in a way towards settlement (Davis and Dugan, 1982). The core elements of mediation are voluntary, nonbinding, and the process itself is also flexible. The decision-making authority rests with the participants themselves. Participants are encouraged to make an informed decision which not only recognizes the legal merit, but also their needs, cultural differences, variations in 
style, and future relationship between the disputants. The mediator facilitates the communication among the disputants (Leung, 2014).

Mediation (or general mediation) differs from litigation mainly in four aspects. First, the timing and procedure of mediation is determined by disputants whilst litigation is controlled by tactics and procedural law. Second, mediation is consensual in nature where parties agree upon an outcome, whereas litigation is adjudicative in nature where the judge or tribunal decides the outcome in accordance with the facts and the law. Third, disputants could choose their own mediators in mediation but not the judge in litigation. Fourth, litigation is mostly conducted in public whilst mediation mostly in private. The benefits of mediation have been widely recognized. It saves the parties' and court's time and costs. It promotes early settlement of dispute and the outcome is usually customized. There is a high compliance rate as the parties voluntarily entered into the agreement or settlement. In some cases, it also helps to preserve the parties' relationship. That said, not all cases are suitable for mediation. Where parties fail to settle, it will add to the costs of litigation. Unlike a court order which can be directly enforced, a mediated settlement agreement is a contract and can only be enforced through litigation.

Family mediation has a similar definition. It is a problem-solving process designed to help separating or divorcing couples to reach their own mutually acceptable agreements regarding the on-going arrangements of their children and related matters. It is a nonadversarial, co-operative decision-making process for issues relating to certain family matters. The family mediation booklet further narrows the scope to only issues arising out of separation and divorce (Hong Kong Judiciary, 2019). Family mediation often has special features of (i) allowing parties to vent their emotions and have them acknowledged and mutualized during the process (Leung, 2014); (ii) engaging parties in the discussion of the parental role relating to child custody, care, control, and support, as well as access to the child (Leung, 2014); (iii) assessing the family resources upon marriage break down (Leung, 2014); and (iv) catering for the power imbalance between husband and wife, if any (Shapiro, 2017). The differences between family mediation and court proceedings are similar to those cited above, except cases in the Family Court in Hong Kong are heard in private.

\section{Mediation model}

There is no one-size fit all practice or model for mediation. The metamodel which provides a systematic framework for mediation could be largely described under six mediation practices, namely, the settlement mediation, facilitative mediation, transformative mediation, expert advisory mediation, wise-counsel mediation, and tradition-based mediation (Alexander, 2008). It could be facilitated towards two dimensions depending on the nature of the dispute: an intervention dimension and interaction dimension. The former deals mainly with the process and problem, such as when to have joint or separate meetings, defining the issues in dispute and when the mediator should intervene in an exchange between the parties. The latter varies among (i) positional bargaining - the back and forth of offers and counteroffers; (ii) interest-based negotiation - the exploration of needs and concerns; and (iii) dialogue - the immediate focus of which is the patterns of interaction between the parties (Alexander, 2010). The intervention of a mediator can also be broadly divided into the facilitative model and the evaluative model. In a facilitative mediation, the mediator intervenes only with the process and will not express an opinion on the merits of the parties' respective cases albeit he or she may cast doubt upon the parties' positions on legal merits, or other matters. On the contrary, an evaluative mediator may assess the merits of the parties' case, predict how a judge or jury would react to the argument or proposition, and inform the parties of his/her assessments.

Family mediation is usually a mix of different approaches. Yet in general, family mediation practitioners usually make it clear that they will facilitate the mediation where children's best 
PAP

24,3

244

interests will put before the parents (HKMAAL, 2021). Some mediation will be child-inclusive mediation where special techniques will be applied to interview the children involved so as to understand their needs and emotions, and the person interviewing the children is usually different from the family mediator. In any child-focused practice, ventilation of emotion and maintenance of relationship between the separating couple are critical. In a family mediation, the process might involve psychology, counselling, and social work, which also address feelings and relationships, encourage participation towards a mutually agreeable solution, a solution that meets different needs and protects the interest of parties (Irving, 2002). Nowadays, separating couples can also appoint Private Family Adjudicators to resolve their disputes. This was firstly initiated on $19^{\text {th }}$ January 2015 for a 3-year pilot scheme under Practice Direction on the Pilot Scheme on the Private Adjudication of Financial Disputes in Matrimonial and Family Proceedings - SL9 (Chief Justice, 2020). There are several organizations providing mediation services such as the Hong Kong Catholic Marriage Advisory Council (2021) and the Hong Kong Family Welfare Society (2021).

\section{Advocating family mediation: brief overview of the global and Hong Kong perspectives}

Research has shown that family mediation could be an effective mechanism for a win-win situation. Also, there is an increasing need to reduce the potential negative effects of divorce (e.g., Cohen and Weitzman, 2016; Rudd et al., 2015). Hence adopting family mediation has been a global trend (Hong Kong Legislative Council, 1999).

In Hong Kong, a recent study has shown family mediation benefits the children. Parents reported that mediation did improve the efficacy of their parentings and also alleviate their children's stress; mediation also helped restore parental responsibilities by setting a good example for their children in terms of adopting an effective means of conflict resolution as well as the basis for co-parenting. Children would feel that the parents' relationship has improved, and they felt more support from their family. Nevertheless, the children might feel powerless during the process as they might not receive as much support as they could have expected (Wong et al., 2019).

Contrary to the positive experiences and outcomes, the use of family mediation has not been active. Between 2013 and 2020, the total number of cases referred to independent mediators through Family Mediation Co-Ordinator's office has stayed at around 230 cases per year except 202 cases in 2020 likely affected by COVID (Hong Kong Judiciary - Mediation, 2021), the utilization is very low when compared with the caseload submitted to the Family Jurisdiction of the District Court with 23,392 cases in 2013 and 17,585 cases in 2020 (Hong Kong Judiciary, 2021). Although the cause of low usage in family mediation needs further investigation, it appears that lack of policy support and lack of formal legal requirement to family mediation might have contributed to it. Currently, there seems to be heavy reliance on the court procedure to encourage family mediation, and it leads to a critical question of whether court procedure could effectively encourage separating parents to use family mediation to protect children's best interests during this painful process, of which insights could be found in Practice Directions issued by Chief Justice of Hong Kong Court of Final Appeal.

\section{PD15.10 and PD31}

\section{PD15.10: Family Mediation}

Part 1 deals with the purposes of the Practice Direction ("PD") as well as the consequences when parties fail to engage in mediation. Whether a party has engaged in a minimum level of participation and their reasonable explanation for not engaging in a mediation could be an admissible material to the court in considering whether to make an adverse costs order against a party under 1.5(i) and 1.5 (ii) of PD15.10. The PD has provided examples, in the form 
of a footnote, of what a minimum level of participation means, such as agreement to identify a mediator, agreement to the rules and one substantive mediation with the mediator. There is case law on reasonableness in general but in large it will depend on the specific circumstances of each case.

Part 2 offers the procedural guidelines relating to the referral of cases to family mediation. There are 5 sections subject to whether the parties are legally represented. If a party is legally represented, the solicitor shall advise the party the availability of family mediation service and how it may assist in the proceedings; solicitor shall provide the party with a copy of the leaflet prepared for promoting family mediation, complete the Certificate as to Family Mediation and declare that the above has been duly performed. If a party acts in person, the Registry would give out the leaflet and inform the party to complete the relevant certificate to declare that he has received the same. The Form requires the parties to indicate whether they would like to engage in mediation. Parts 3 and 4 offer guidelines with regard to interlocutory proceedings. Part 3 generally explains how to apply for family mediation and states that litigation proceedings will not be stayed automatically by reason of any application to mediation. Part 4 is addressed to legally represented parties only and it stipulates the general procedure of an interim stay of the underlying proceedings where mediation has been contemplated. The court may give directions appropriate to resolve relevant points arising during mediation or stay the proceedings under the court's own accord.

\section{PD31: Mediation}

PD31 is divided into 3 parts. Part A focuses on how the court will exercise its discretion on costs for a party's unreasonable refusal to participate in mediation. Part B stipulates how mediation should be initiated for parties who are legally represented. Part $\mathrm{C}$ provides that the court may direct the parties who are not legally represented to initiate mediation following procedures set out in Part B and thus should be considered in tandem with Part B.

Part A begins by stating the purposes and scope of the PD to include all civil proceedings in the Court of First Instance and the District Court begun by writ with a few exceptions (Appendix 1 of PD31). It also states that the court may impose an adverse costs order against a party who has unreasonably failed to engage in mediation (paragraph 4 of PD31). It indicates such order would not be imposed if the parties have shown a minimum level of participation or have a reasonable explanation for not engaging in mediation. Paragraph 5 of PD31 provides that an adverse costs order will not be made if:

(1) The party has engaged in mediation to the minimum level of participation agreed to by the parties or as directed by the Court prior to the mediation ...

(2) A party has a reasonable explanation for not engaging in mediation ... active without prejudice settlement negotiations .... is likely to provide such a reasonable explanation ... parties are actively engaged in some other form of ADR (alternative dispute resolution procedure) to settle the dispute may also provide a reasonable explanation...

When considering the reasonableness of refusing to participate in mediation, the court will look at a wide range of factors and a non-exhaustive list has been provided in Halsey $v$ Milton Keynes NHS Trust [2004] 1 WLR 2002 (Martin, 2009):

(a) the nature of the dispute;

(b) the merit of the case, specifically "the fact that a party reasonably believes that he has a strong case is relevant to the question whether he has acted reasonably in refusing ADR";

(c) the extent to which other settlement methods have been attempted; 
(d) whether the costs of ADR would be disproportionately high;

(e) whether any delay in setting up and attending the ADR would have been prejudicial; and

(f) whether ADR has a reasonable prospect of success.

However, it should be noted that an adverse costs order is only an exception to the costs should follow the event principle and could not be justified unless it is shown that the successful party acted unreasonably in refusing to agree to ADR. The burden of proof is on the unsuccessful party.

Parts $\mathrm{B}$ and $\mathrm{C}$ set out the mechanism of the filing of a Mediation Certificate as per the time tabling questionnaire under $\mathrm{O} 25 \mathrm{r} 1 \mathrm{RHC}$. It indicates whether or not a party is willing to attempt mediation after solicitors have explained to their client the availability of mediation and the cost implication (Appendix B of PD31); then it stipulates that the party who wishes to attempt mediation should serve a Mediation Notice (Appendix C of PD31) on the other party, who should, within 14 days upon receipt of the Mediation Notice, serve a Mediation Response (Appendix D of PD31). The parties should resolve between themselves any differences as to the proposals made in the Mediation Notice and Response, and record them in the Mediation Minute, failing which either or both parties may make an application to the Court for direction. The court may stay the proceedings upon application by either party or on its own motion (paragraph 16 of PD31).

\section{Is family mediation a must?}

At first sight, the court appears to be more determined and proactive in ensuring that the benefits of family mediation are brought to the attention of the litigants. PD15.10 requires that the parties be given a leaflet when they commence court proceedings. The leaflet briefly sets out what family mediation is and highlights its benefits which includes a "User's Review and Recommendation session". Whereas under PD31, the court only needs to see evidence of an exploration of mediation which includes: A Mediation Notice (Appendix C of PD31), Response (Appendix D of PD31) and Minutes without requiring delivery of information that promotes mediation.

A closer evaluation between the content of PD15.10 and PD31 appears to unveil that the effort of guiding family mediation under PD15.10 might not be as much as that of general mediation under PD31. It could be reflected in different handlings of the procedural requirements.

Part 2 of PD15.10 details the documentary requirements between legally represented and unrepresented parties. It sets out the step for what would fulfill the court's requirements. Taking 2.5.1 of PD15.10, which relates to the other respondent or intervening party, as an example, it specifies the role of each officer, where: the solicitor shall complete the certificate in Appendix 4; the Registry staff shall check referral to the coordinator for parties attempting family mediation; the Coordinator will contact the other parties. Similar instruction is found in PD31: the parties would appoint the mediator through Mediation Notice and Responses but without the role of the coordinator - indicating that the judicial officers (usually the legal representative of the parties) shall ensure that the parties have participated in mediation. Whilst a clear division of labour describing the operational flow ensures engagement of the judicial officers, their roles appear to be restricted to passing the information to the parties in this process. It may be unclear how such a message is delivered and whether parties are sufficiently informed of the function of mediation. For example, there would be a significant difference if the judicial officers only hand over the leaflet to the parties versus the officers have a 30-minute one-on-one session explaining the details of the leaflet. 
Another example is the role of the court. As seen, the court did control the quality of the integrated office, but this is not mentioned in relevant documents and hence should the judicial officers only hand over the leaflet to the parties, they might not be aware of the involvement and supervision from the court even if whether the parties have engaged in family mediation appeared to be outside the court. In an extreme case where parties are not represented legally, the court would not know whether the leaflet is duly read and noted because the requirement in writing appears to be stated as "I have given the leaflet on Family Mediation. .." under Appendix 4 of PD15.10, it does not require the parties to read it. Also, it is optional for parties to explain why they do not participate family mediation as per PD15.10, whilst it is mandatory to explain under Appendix B of PD31.

It is further observed that the handling of the stay of proceedings may indicate a different emphasis. Even though there are provisions in both PD15.10 and PD31 for the parties to have the rights to apply for stay or the court might take its own motion to stay the proceedings under paragraphs 14, 16, 17 of PD31 and paragraphs 4.1 of PD15.10 respectively, it is stated "Any application for Family Mediation ... shall not lead to an automatic stay in the litigation proceedings." under paragraph 3.2 of PD15.10; such provision is not stated in PD31. It may give an impression (although possibly not true) that the court has reserved its rights not to stay the proceedings for family mediation unless the parties apply for it. Also, parties acting in person are not obliged to follow paragraph 3.2 of PD15.10 and are referred back to Part C of PD31 which direct the party to the court's direction to consider whether mediation is desirable. It may not be easy for litigants in person (often lay persons) to understand these procedures, especially in terms of the role of the court and the consequences of not engaging in mediation and family mediation. On the other hand, whilst it is a procedural matter because family mediation has not started yet, and the court shall continue to rule on non-mediated matters governed by related Ordinances under Part D of Practice Direction 15.12 (Chief Justice, 2011), this is unlikely a reason to explain the different treatment because otherwise separate proceedings should be in place and there will not exist the issue of an interim stay of the proceedings. While in practice, a stay of proceedings is identical between general and family mediation where the parties will apply to reschedule hearing dates pending mediation, it is unclear why relevant provisions in PD31 is written differently in this regard.

The enthusiasm shown in promoting family mediation may not bear fruit if one only relies on the guidance from the Practice Directions. However, there are other initiatives that were not mentioned in PD15.10 such as the role of the Integration Office. PD15.10 serves as a document to facilitate settlement of disputes through family mediation with underlying objectives and costs consequences (1.1 of PD15.10), then requests the solicitor to advise the availability of family mediation services and gives the leaflet prepared by the Integrated Office (2.1.1. of PD15.10). It appears to miss important instructions such as "explain", "promote", "facilitate" the use of family mediation. Neither does it request any evidence of how solicitors offer their advice, or at least document the reasons for refusal to mediate. It may be less than sufficient from a policy perspective because the efforts appear to stop at information dissemination and go no further.

This observation could be examined through illustrating the findings from one detailed analysis between the content of the appendices of PD31 and PD15.10. In Appendix B of PD31, Part I asks two questions: if (i) the Plaintiff / Defendant are willing to attempt mediation and (ii) if not, "please state the reasons in this Certificate... such reasons or additional reasons should be set out". In Part II, the solicitor must "explain" to the client the availability, cost position and PD31. In Part III, the party must acknowledge that they "understand" PD31. In Appendix 2 of PD15.10, it requires solicitor to "explain", the respondent only need to "certify" that they are "advised" of the Underlying Objective and have "received" the leaflet. It is optional for the parties to give reasons. For a respondent acting in person, they just need to confirm they "receive" the leaflet, and parties are not required to provide reasons for non- 
PAP

24,3

\section{8}

participation but instead simply an indication of their intention to participate or not under Appendix B of PD31 and Appendix 2 of PD15.10. It is also noted that PD15.10 also does not require parties to "understand" PD15.10 or the leaflet, unlike PD31 (under Part III and Appendix B of PD31) which requests parties to understand the Practice Direction on Mediation. It may give the impression that general mediation is more important or less complex than family mediation and hence the use of these languages.

\section{The court's duty to protect children and its challenges}

The court is highly concerned about children's matters. In SKP v Y, ITT (Legal Terminology to be used in Child/ren's Arrangements) FCMC 17772 / 2011 (District Court Hong Kong SAR, 2012), the court laid down in detail the arrangements concerning the child's life after her parents are divorced. It covered many aspects, with a detailed timetable for weekdays and weekends including the arrangements for shower time and story time. It also defines the terminology such as joint care, control, and custody. This case clearly illustrates that the court is readily prepared to step in if the parents are not able to put children's best interests before theirs, or that the parties are in such high conflict situation that it is unlikely for them to arrange in the best interest of their children.

A more refined approached is found in the Proposed Bill. It follows the child's best interests principles as per the United Nations Convention on the Rights of the Child which was adopted in Hong Kong on 7 September 1994, and advocates greater involvement of both parents in the lives of the children. The concept of Parental Responsibility could have achieved the aim to eliminate the distinction between a "winner" and a "loser" when negotiating children's matters. These are reflected in the Proposed Bill through introducing for example the Child Arrangements Orders, availability for grandparents to apply for parental responsibility, repealing terms under Section 30 of the Proposed Bill which represent outdated perceptions of parental proprietary rights such as "Custody", "Control", and "Access". Through the emphasis of dual parental responsibilities, the Proposed Bill departs from the old approach which has resulted in the dwindling contact between the children and the non-custodial parent. Such dual parental responsibilities are reckoned through a wide variety of well-defined court orders under Part 2 (5) of the Proposed Bill. The Proposed Bill also promotes the active involvement of separating couples in the lives of their children by expanding the old "rights" and "authority" over the children to the concept of shared responsibility. Although the scope of this paper is confined to the analysis of the wording in PD15.10 and PD31, along with the general purpose of the Proposed Bill, without drilling into the legal implications thereof, the question on how the provisions of the Proposed Bill might affect the way such purposes are achieved warrants further research. It is a clear attempt to nurture a new culture by shifting the litigants' mindset from "winning or losing" rights over their children to dual parental responsibilities despite their separation.

Practice Direction 15.13 has made it clear that "the best interest of children remains the court's paramount concern" (Chief Justice, 2016, paragraph 2), and the court readily plays a role in achieving the child's welfare albeit its limitations. SKP is a prominent Hong Kong example. The order in SKP stipulates that those arrangements made by the court "will need to change over time" (paragraph 24, SKP), which is obvious because the interest of a 3.5-year-old girl (as in $S K P$ ) would not be the same when she turns 6. Having said that, whether the parents would require further court proceedings to resolve their differences has yet to be seen. Even if the parties have to resort to the court for direction, it is impossible for the law to lay down standardized arrangements for children attaining different ages. It is ineffective and somewhat impractical in light of the ever-changing dynamics and circumstances. The law is not the answer in this aspect and would be dangerous if the law ventures into directing individuals' lives and behavior at such level of detail. 


\section{Policy implications}

Whilst studies have shown that the law could have already helped facilitate the use of family mediation (e.g., Batagol, 2011), the proposed change to the Children Proceedings (Parental Responsibility) Bill is still necessary. The Proposed Bill was not enacted primarily because of the additional resources and support measures needed before the legislation. Since 2018/19, more resources have been proposed as a priority to support continuing parental responsibility for children even after divorce or separation. Although the recommendations from the Law Reform Commission have also been adopted in practice, the efforts should be stronger by promoting family mediation through legislation. Relying on Practice Directions and lawyers is far from sufficient. The court should only serve as the last line of defence in children's matters. The role of court serving as a safe haven should be re-considered as the literature has long-discussed (e.g., Lynch, 2019).

Family is the foundation of a society; family stability and children's interest no doubt are matters of public interest. Yet, it is also equally critical to acknowledge that each family has its own unique situation, and the court may not be in a position to prescribe all possible steps to fit the needs of the children. According to the Proposed Bill, the move from rights-based to responsibility-based parenthood should be further supplemented by the engagement of family mediation despite some known difficulties such as lack of mechanism for children to express their disagreement regarding custody and visitation arrangements (Hong Kong Legislative Council, 2018). It might be time to revisit these rationales again for sake of children's best interests, which is always a top priority for the society and in which the need for a solution is imminent.

What has not been mentioned so far is the Practice Direction 15.13 - Children Dispute Resolution (Chief Justice, 2016). There had been a Pilot Scheme on Children's Dispute Resolution carried out by the Family Court from 3 October 2012 to 31 March 2016 to support mothers and fathers with the judge acting as a conciliator to discuss the children-related arrangement post-separation on the basis of the children's best interests. It is done alongside with Practice Direction 15.11 - Financial Dispute Resolution Pilot Scheme (Chief Justice, $2012 b)$ which deals with financial matters. It further demonstrates the keen concern of the court to resolve children's matters. However, these Practice Directions, like other Practice Directions, serves only as procedural guidance in aiding court proceedings. The parents would also need practical advice such as how to handle their emotions and set their priorities, such that they would focus better on their responsibilities as parents, not only their rights. To date the Pilot Scheme is still incorporated into court proceedings but it could have been made more explicit and known to be a permanent process by the general public.

\section{Conclusion}

In a difficult situation where a couple seeks separation, but both continued to be bound due to their parental responsibilities, family mediation may help. It is recognized that there are initiatives in Hong Kong to bring the children's voice to the negotiation table. For example, the current External Mediator Master Scheme (Ho, 2020) could be applied to family cases, and the discussion of the legal rights of unmarried fathers (hongkongdivorce.com, 2020). However, these initiatives do not seem to be operating at policy level, as they should be. These initiatives promoted by the Judiciary should be supplemented and promoted by policy, law and supporting services so as to facilitate the transition from rights-based negotiation to a responsibility-based negotiation, as well as to drive the society to provide more support for parents' post-negotiation (e.g., exercise of their visitation rights). Whether a good judge could be equipped to issue a suitable judgment for the children for the rest of their childhood is always a debate that would reach no conclusion, parents with proper aid are always the most qualified to make such a call.
Upholding parental responsibility 
PAP

24,3

Whilst policy and resources support are vital to the implementation of a piece of legislation, the reverse can also be true. Even if the law might seem to be coercing the parents to adopt a different mindset, and even if it may be more authoritative to receive a court order which is issued after considering expert opinions on children's matter, family mediation could still play its role to facilitate long-term parental decision-making responding to children's needs at different stages. Child protection, as argued in this paper, is the most important social topic that still requires legal enforcement.

When considering a divorce or separation, the first question the parties usually ask is "what will court say about the children?". The correct question to ask should be "what is best for the children and what could parents do?". Family mediation should be further promoted through enacting at least its spirit in the Proposed Bill, so as to establish a legal foundation to direct parties to negotiate and communicate, to seek and benefit from professional guidance on a continuous basis, and to seek alternative channels to resolve disputes other than the court room such as collaborative lawyering (e.g., Tesler, 2004; Herman, 2013; Gamache, 2005). Relying on Practice Directions might not be sufficient, and the court should only act as the last line of defense.

Still, mediation is conducted in the shadow of the law. Parties would inevitably negotiate in contemplation of the outcome of litigation. Their mindsets are likely to be framed by how their legal cases are put which focus on their rights and the wrongs they have suffered. Although Family Mediator has the "overriding duty to protect the best interest of the children" (Part A(h)(ii), HKMAAL, 2021), a legal foundation would still better prepare them to adopt a child-focus approach and intervene the process to give priority to children's interests or parental responsibilities. Albeit the Proposed Bill has not been enacted, there is nothing to prevent the promulgation of its spirit. In fact, in anticipation of the legislative change, Family Judges have been having recourse to the Welfare Checklist as set out by the Law Reform Commission, which was also stated in Part 2(3) of the Proposed Bill. The same spirit could have been extended to family mediation. If parents are well educated on what the court would look at, they might be motivated to negotiate in that direction. It would be encouraging to see if more could be done by the Administration or the Judiciary to equip the mediators and parents in this regard, notwithstanding they are the guardian of children's interest in matrimonial proceedings.

Currently, it appears to have no known research to see how family mediation might be used to achieve the spirit of the Proposed Bill as an alternative to litigation. As stated at the beginning of this paper, it is now an appropriate time to reflect on whether the Proposed Bill can be incorporated into a consensual approach to bring the best possible arrangement for children in family proceedings.

\section{References}

Alexander, N. (2008), "The mediation metamodel: understanding practice", Conflict Resolution Quarterly, Vol. 26 No. 1, pp. 97-123.

Alexander, N. (2010), Mediation: Process and Practice in Hong Kong, LexisNexis, Hong Kong.

Batagol, B. (2011), Bargaining in the Shadow of the Law? The Case of Family Mediation, Themis Press, Annandale, N.S.W.

Chief Justice (2011), "Practice Direction 15.12 Matrimonial proceedings and family proceedings", available at: https://legalref.judiciary.hk/lrs/common/pd/pdcontent.jsp?pdn=PD15.12. htm\&lang=EN (accessed 30 March 2021).

Chief Justice (2012a), "Practice Direction 15.10 Family mediation", available at: https://legalref. judiciary.hk/lrs/common/pd/pdcontent.jsp?pdn=PD15.10.htm\&lang $=\mathrm{EN} \quad$ (accessed 29 August 2021). 
Chief Justice (2012b), "Practice Direction 15.11 Financial Dispute Resolution Pilot Scheme", available at: https://legalref.judiciary.hk/doc/pd/eng/PD15.11.htm (accessed 29 August 2021).

Chief Justice (2014), "Practice Direction 31 Mediation", available at: https://legalref.judiciary.hk/lrs/ common/pd/pdcontent.jsp?pdn=PD31.htm\&lang $=$ EN (accessed 29 August 2021).

Chief Justice (2016), "Practice Direction 15.13 Children's dispute resolution", available at: https:// legalref.judiciary.hk/doc/npd/eng/PD15.13.htm (accessed 29 August 2021).

Chief Justice (2020), "Practice Direction SL9 Pilot scheme on private adjudication of financial disputes in matrimonial and family proceedings", available at: https:/legalref.judiciary.hk/lrs/common/ $\mathrm{pd} /$ pdcontent.jsp?pdn=PDSL9.htm\&lang=EN (accessed 16 September 2021).

Cohen, G.J. and Weitzman, C.C. (2016), "Helping children and families deal with divorce and separation”, Pediatrics, Vol. 138 No. 6, pp. 1019-1123.

Davis, H.E. and Dugan, M.A. (1982), "Training the mediator", Peace and Change, Vol. 8 No. 2/3, pp. 81-90.

District Court Hong Kong SAR (2012), "SKP v Y, ITT (Legal Terminology to be used in Child/ren's Arrangements) FCMC 17772 / 2011", available at: https:/legalref.judiciary.hk/lrs/common/ search/search_result_detail_frame.jsp?DIS $=85958 \& \mathrm{QS}=\% 2 \mathrm{~B} \& \mathrm{TP}=\mathrm{JU}$ (accessed 29 August 2021).

Gamache, S. (2005), “Collaborative practice: a new opportunity to address children's best interest in divorce", Louisiana Law Review, Vol. 65 No. 4, pp. 1455-1485.

Herman, G. (2013), "Family Law: why collaborative divorce continues to decline in popularity", Commentary, Wisconsin Law Journal, available at: https://wislawjournal.com/2013/02/04/familylaw-why-collaborative-divorce-continues-to-decline-in-popularity/ (accessed 29 August 2021).

Ho, D. (2020), "Report on the external mediation master scheme", 5 November, available at https:// mediation.judiciary.hk/en/doc/Master\%20Dick $\% 20 \mathrm{Ho} \% 27 \mathrm{~s} \% 20$ presentation $\% 20$ at $\% 20$ the $\%$ 20Legal\%20Week\%202020_05.11.2020.pdf (accessed 29 August 2021).

Hong Kong Catholic Marriage Advisory Council (2021), "Family mediation", available at: https://www. cmac.org.hk/eng/rs_Family_mediation_service (accessed 29 August 2021).

Hong Kong Family Welfare Society (2021), "Mediation services and divorce services", available at https://www.hkfws.org.hk/en/how-we-help/mediation-services-and-divorce-services (accessed 29 August 2021).

Hong Kong Judiciary (2019), "Family mediation: guide to court services", available at: http://mediation. judiciary.hk/tc/doc/FamilyMediation.pdf (accessed 29 August 2021).

Hong Kong Judiciary (2021), "Hong Kong Judiciary Annual Report", available at: https://www. judiciary.hk/en/publications/publications.html\#annu_report (accessed 16 September 2021).

Hong Kong Judiciary - Mediation (2021), "Mediation figures and statistics", available at: https:// mediation.judiciary.hk/en/figures_and_statistics.html\#msfcimfp (accessed 29 August 2021).

Hong Kong Labour and Welfare Bureau (2015), "Proposed Legislation: Children Proceedings (Parental Responsibility) Bill", available at: https:/www.lwb.gov.hk/en/parentalresponsibility_consult/ doc/Draft_Bill_(Eng).pdf (accessed 29 August 2021).

Hong Kong Legislative Council (1999), "Report of the Working Group to consider a Pilot Scheme for the introduction of mediation into Family Law Litigation in Hong Kong", available at: https:// www.legco.gov.hk/yr99-00/english/panels/ajls/papers/1045e02.pdf (accessed 27 August 2021).

Hong Kong Legislative Council (2018), "Updated background brief prepared by the Legislative Council Secretariat for the meeting on 12 March 2018 - Child custody and access in Hong Kong”, LC Paper No. CB(2) 981/17-18(04), available at: https://www.hkreform.gov.hk/en/ publications/raccess.htm (accessed 29 August 2021).

Hong Kong Mediation Accreditation Association Limited (HKMAAL) (2021), "Guidelines for professional practice of family mediators", available at: http:/www.hkmaal.org.hk/en/ MediationRules_GuidelinesForProfessional.php (accessed 27 August 2021).

Upholding parental responsibility

\section{.}


PAP

24,3

hongkongdivorce.com (2020), "Custody and access of children of unmarried parents", available at: https://www.hongkongdivorce.com/custody-and-access-of-children-of-unmarried-parents/ (accessed 29 August 2021).

Irving, H.H. (2002), Family Mediation: Theory and Practice with Chinese Families, Hong Kong University Press, Hong Kong.

Judiciary of the HKSAR (2021), "Evaluation study on the pilot scheme on family mediation", available at: http://www.judiciary.hk/en/publications/hkpu_finalreport.pdf (accessed 29 August 2021).

Leung, R.H.M. (Ed.) (2014), Hong Kong Mediation Handbook, 2nd edition, Sweet and Maxwell, Hong Kong.

Lynch, K. (2019), Hong Kong's Children Proceedings (Parental Responsibility) Bill: comparative family law reform and multidisciplinary collaboration, Canadian Journal of Family Law, Vol. 32 No. 1, pp. $77-143$.

Martin, R. (2009), Hong Kong Civil Justice Reform Practice Manual, Sweet and Maxwell, Hong Kong.

Moore, C.W. (2003), The Mediation Process: Practical Strategies for Resolving Conflict, Jossey-bass, San Francisco.

Rudd, B.N., Ogle, R.K., Holtzworth-Munroe, A., Applegate, A.G. and D’Onofrio, B.M. (2015), “Childinformed mediation study follow-up: comparing the frequency of relitigation following different types of family mediation. Psychology”, Psychology, Public Policy, and Law, Vol. 21 No. 4, pp. $452-457$.

Shapiro, D. (2017), Negotiating the Nonnegotiable: How to Resolve your Most Emotionally Charged Conflict, Penguin, New York, N.Y.

Tesler, P.H. (2004), “Collaborative family law”, Pepperdine Dispute Resolution Law Journal, Vol. 4 No. 3, pp. 317-336.

Wong, M.M., Ma, J.L. and Xia, L. (2019), “A qualitative study of parents' and children's views on mediation”, Journal of Divorce and Remarriage, Vol. 60 No. 6, pp. 418-435.

Yarn, D.H. (1999), Dictionary of Conflict Resolution, Jossey-Bass, San Francisco.

\section{About the author}

Sau-wai Law is a Senior Lecturer in the Department of Law and Business at Hong Kong Shue Yan University. Before joining Shue Yan University in January 2021, he had over 14 years of banking experience in Hong Kong, taking up various roles as a credit risk manager, private banker, and strategic planning specialist. He is a $\mathrm{PhD}$ candidate at Faculty of Law at HKU with research focus on banking and finance law, contract law, and arbitration and dispute resolution. Sau-wai Law can be contacted at: swlaw@hksyu.edu

For instructions on how to order reprints of this article, please visit our website:

www.emeraldgrouppublishing.com/licensing/reprints.htm

Or contact us for further details: permissions@emeraldinsight.com 